\title{
POLA KUMAN PENYEBAB OTITIS EKSTERNA DAN UJI KEPEKAAN ANTIBIOTIK DI POLIKLINIK THT-KL BLU RSUP \\ PROF. Dr. R. D. KANDOU MANADO \\ PERIODE NOVEMBER - DESEMBER 2013
}

\author{
${ }^{1}$ Monica Lie Sedjati \\ ${ }^{2}$ Oraetlabora Immanuel Palandeng \\ ${ }^{2}$ Olivia Claudia Pingkan Pelealu \\ Bagian / SMF Telinga Hidung Tenggorokan - Bedah Kepala Leher Fakultas Kedokteran \\ Universitas Sam Ratulangi Manado \\ Email : $\underline{\text { monica.sedjati@yahoo.com }}$
}

\begin{abstract}
Otitis externa is an inflammation of the ear canal that occur in acute or chronic stage caused by an infection of bacteria, viruses or fungi. The extent of the use of antimicrobials in community can lead to resistant. This study aimed to know the bacteria pattern of otitis externa and the antibiotic sensitivity test at Otorhinolaryngology Departement Prof. Dr. R. D. Kandou Hospital Manado period of November - December 2013. This is a descriptive prospective study. A total of 22 otitis externa patients, the largest age group was adults 15-49 years old with 13 persons (59,1\%). Most identified gender was female by 15 people (68.2\%). All the patients diagnosed with a history of trauma. The most complained symptoms were pruritus 19 people $(86,3 \%)$. There were 8 types of bacteria that has been identified and the most identified were 4 samples $(18,2 \%)$ as Staphylococcus aureus and 4 samples (18,2\%) as Pseudomonas aeruginosa. In susceptibility test, the most sensitive antibiotic were Levofloxacin and Ciprofloxacin by 20 samples (100\%). The most resistant was Clindamycin 20 sampel (100\%). Conclusions : The most identified bacteria were Staphylococcus aureus and Pseudomonas aeruginosa with 4 samples (18.2\%). The most sensitive antibiotic were Levofloxacin and Ciprofloxacin 20 samples (100\%).

Key Words : otitis externa, bacterial pattern, sensitivity test.
\end{abstract}

\begin{abstract}
Abstrak : Otitis eksterna merupakan peradangan pada liang telinga yang terjadi secara akut maupun kronis yang disebabkan infeksi oleh bakteri, virus maupun jamur. Luasnya penggunaan antimikroba di kalangan masyarakat dapat berujung pada keadaan resisten. Penelitian ini bertujuan untuk mengetahui pola kuman penyebab otitis eksterna dan uji kepekaan antibiotik di poliklinik THT-KL BLU RSUP Prof. Dr. R. D. Kandou Manado periode November-Desember 2013. Penelitian ini bersifat deskriptif prospektif. Dari 22 orang pasien otitis eksterna, diperoleh kelompok umur terbanyak adalah kelompok umur dewasa 15-49 tahun sebanyak 13 orang (59,1\%). Jenis kelamin terbanyak adalah perempuan berjumlah 15 orang (68,2\%). Semua pasien yang terdiagnosis memiliki riwayat trauma. Gejala yang terbanyak dikeluhkan pasien otitis eksterna adalah pruritus berjumlah 19 orang (86,3\%). Terdapat 8 jenis bakteri yang teridentifikasi dan terbanyak adalah Staphylococcus aureus 4 sampel (18,2\%) dan Pseudomonas aeruginosa 4 sampel (18,2\%). Pada uji kepekaan, antibiotik dengan sensitivitas tertinggi adalah Levofloxacin dan Ciprofloxacin 20 sampel (100\%). Angka resistensi tertinggi ditunjukkan oleh Clindamycin 20 sampel (100\%). Kesimpulan : Bakteri terbanyak adalah Staphylococcus aureus dan Pseudomonas aeruginosa masing -masing 4 sampel (18,2\%). Angka kepekaan tertinggi ditunjukkan oleh Levofloxacin dan Ciprofloxacin 20 sampel (100\%).
\end{abstract}

Kata Kunci : otitis eksterna, pola kuman, uji kepekaan. 
Otitis eksterna merupakan peradangan pada liang telinga yang terjadi secara akut maupun kronis. Penyebabnya dapat berupa infeksi oleh bakteri, virus maupun jamur. ${ }^{1,2}$ Insidens otitis eksterna akut terjadi pada 4 dari 1000 anak dan orang dewasa per tahun. ${ }^{3}$ Laporan pertama dari CDC (Center for Disease Control and Prevention) yang menggambarkan secara keseluruhan epidemiologi otitis eksterna akut di Amerika Serikat, diperkirakan bahwa 2,4 juta kunjungan per tahun yang terdiagnosis di pusat kesehatan merupakan kasus otitis eksterna akut (8,1 kunjungan per 1000 populasi). ${ }^{4}$ Adapun penelitian di poliklinik THT-KL BLU RSUP Prof. Dr. R. D. Kandou Manado pada periode Januari - Desember 2011 memperlihatkan bahwa dari 5.297 pengunjung terdapat $440(8,33 \%)$ kasus otitis eksterna. ${ }^{5}$

Otitis eksterna akut dapat dibagi menjadi dua, yaitu otitis eksterna sirkumskripta dan otitis eksterna difusa. Keduanya berbeda dari segi letak peradangan, gejala yang ditimbulkan, serta kuman penyebab. Otitis eksterna sirkumskripta biasanya disebabkan oleh kuman Staphylococcus aureus atau Staphylococcus albus. Sedangkan otitis eksterna difusa terutama disebabkan oleh golongan Pseudomonas. ${ }^{1,2}$

Suatu studi pada populasi sampel menunjukkan 53\% kasus otitis eksterna disebabkan oleh kuman gram negatif, yaitu Pseudomonas. Dan 46\% lainnya merupakan kuman gram positif yaitu Staphylococcus aureus dan Staphylococcus lainnya. Sisanya 1,7\% merupakan infeksi jamur. ${ }^{6}$

Dewasa ini kata antimikroba dan antibiotik sudah tidak asing lagi. Antimikroba adalah obat pembasmi mikroba. Sedangkan antibiotik adalah zat yang dihasilkan oleh suatu mikroba yang dapat menghambat maupun membasmi mikroba yang lain. Penggunaan antimikroba sebagai agen pembasmi mikroba di kalangan masyarakat sudah sangat luas. Luasnya penggunaan antimikroba ini dapat berujung pada suatu keadaan dimana kuman patogen sudah tidak lagi berespon terhadap antimikroba yang digunakan yang dikenal dengan istilah resisten. Resistensi suatu antimikroba dipermudah oleh beberapa faktor seperti penggunaan antimikroba yang sering, irasional, berlebihan dan penggunaan dalam jangka waktu yang lama. ${ }^{7}$ Penelitian ini bertujuan untuk mengetahui pola kuman penyebab otitis eksterna dan uji kepekaan antibiotik di poliklinik THT-KL BLU RSUP Prof. Dr. R. D. Kandou Manado periode November-Desember 2013.

\section{METODE PENELITIAN}

Penelitian ini bersifat deskriptif prospektif dan dilaksanakan pada bulan November 2013 Desember 2013. Pengambilan sampel dilakukan di Poliklinik THT-KL BLU RSUP Prof. Dr. R. D. Kandou Manado dan pemeriksaan sampel dilakukan di Laboratorium Mikrobiologi RSUP Prof. Dr. 
R. D. Kandou Manado. Subjek penelitian ini adalah semua pasien otitis eksterna yang datang berobat ke Poliklinik THT-KL BLU RSUP Prof. Dr. R. D. Kandou Manado periode November Desember 2013, dengan kriteria inklusi yaitu pasien otitis eksterna dengan gejala otore, tidak mengkonsumsi antimikroba sekurang-kurangnya 5 hari sebelum pengambilan sampel dan keadaan membran timpani intak. Adapun kriteria eksklusinya yaitu menolak untuk ikut dalam penelitian dan pasien otitis eksterna dengan komplikasi otitis media. Variabel penelitian ini antara lain : umur, jenis kelamin, faktor resiko, gejala klinis, bakteri yang teridentifikasi dan sensitivitas bakteri terhadap antibiotik.

\section{HASIL PENELITIAN}

Selama periode penelitian, diperoleh 22 sampel sekret telinga dari pasien yang terdiagnosa otitis eksterna di Poliklinik THT-KL BLU RSUP Prof. Dr. R. D. Kandou Manado. Bila digolongkan menurut kelompok umur, diperoleh hasil yang dapat dilihat dalam tabel berikut :

Tabel 4.1 Distribusi Pasien Otitis Eksterna Menurut Kelompok Umur

\begin{tabular}{ccc}
\hline Kelompok Umur & $\mathrm{n}$ & $\%$ \\
\hline $0-14$ tahun & 4 & 18,2 \\
$15-49$ tahun & 13 & 59,1 \\
$>50$ tahun & 5 & 22,7 \\
Jumlah & 22 & 100 \\
\hline
\end{tabular}

Tabel 4.1 menunjukkan bahwa pasien otitis eksterna terbanyak adalah pada kelompok umur dewasa 15-49 tahun sebanyak 13 orang (59,1\%). Distribusi pasien berdasarkan jenis kelamin juga dapat dilihat pada tabel dibawah ini :

Tabel 4.2 Distribusi Pasien Otitis Eksterna Menurut Jenis Kelamin

\begin{tabular}{ccc}
\hline Jenis Kelamin & $\mathrm{n}$ & $\%$ \\
\hline Perempuan & 15 & 68,2 \\
Laki - laki & 7 & 31,8 \\
Jumlah & 22 & 100 \\
\hline
\end{tabular}

Pada tabel 4.2 dapat dilihat bahwa pasien yang terdiagnosa otitis eksterna berjumlah 22 orang. Jenis kelamin terbanyak adalah perempuan berjumlah 15 orang dan laki-laki berjumlah 7 orang.

Saat pengambilan sampel sekret telinga, juga dilakukan anamnesis singkat mengenai faktor yang meningkatkan resiko penyakit. Hasil penelitian mengenai faktor resiko yang teridentifikasi dapat dilihat pada tabel dibawah ini. 
Tabel 4.3 Faktor Resiko yang Teridentifikasi

\begin{tabular}{ccc}
\hline Faktor Resiko & $\mathrm{n}$ & $\%$ \\
\hline Trauma & 22 & 100 \\
Berenang & 0 & 0 \\
Penggunaan Hearing aids & 0 & 0 \\
Jumlah & 22 & 100 \\
\hline
\end{tabular}

Dari tabel 4.3 diketahui bahwa semua pasien yang terdiagnosis memiliki riwayat trauma (100\%) yang merupakan faktor resiko otitis eksterna.

Dua gejala yang merupakan karakteristik dari otitis eksterna adalah rasa ketidaknyamanan telinga dan keluarnya cairan dari kanalis eksternal (otore). Ketidaknyamanan telinga yang dirasakan dapat berupa gatal (pruritus) saja hingga nyeri hebat (otalgia) yang diperburuk oleh gerakan telinga, termasuk aktivitas mengunyah. ${ }^{8}$ Berikut tabel yang menunjukkan hasil penelitian mengenai gejala klinis yang teridentifikasi.

Tabel 4.4 Gejala Klinis yang Teridentifikasi

\begin{tabular}{ccc}
\hline Gejala Klinis & $\mathrm{n}$ & $\%$ \\
\hline Pruritus & 19 & 86,3 \\
Otalgia & 17 & 77,2 \\
\hline
\end{tabular}

Pada tabel 4.4 ditemukan bahwa gejala yang dikeluhkan pasien dengan otitis eksterna dalam penelitian ini adalah pruritus berjumlah 19 orang dan otalgia berjumlah 17 orang.

Pemeriksaan yang dilakukan di Laboratorium Mikrobiologi RSUP Prof. Dr. R. D. Kandou Manado selama periode November - Desember 2013 memberikan hasil dari 22 sampel yang diperiksa terdapat 20 sampel dengan pertumbuhan bakteri dan 2 sampel tanpa pertumbuhan bakteri. Berikut tabel yang menunjukkan hasil penelitian mengenai jenis bakteri yang teridentifikasi.

Tabel 4.5 Bakteri yang Teridentifikasi

\begin{tabular}{ccc}
\hline Bakteri & $\mathrm{n}$ & $\%$ \\
\hline Staphylococcus aureus & 4 & 18,2 \\
Pseudomonas aeruginosa & 4 & 18,2 \\
Enterobacter aerogens & 3 & 13,6 \\
Pseudomonas putrefaciens & 3 & 13,6 \\
Alcaligenes faecalis & 2 & 9,1 \\
Proteus mirabilis & 2 & 9,1 \\
Acinetobacter baumannii & 1 & 4,6 \\
Proteus rettgeri & 1 & 4,6
\end{tabular}


Dari tabel 4.5 ditunjukkan bahwa bakteri yang teridentifikasi dalam penelitian ini cukup beragam, yaitu Staphylococcus aureus 4 sampel (18,2\%), Pseudomonas aeruginosa 4 sampel (18,2\%), Enterobacter aerogens 3 sampel (13,6\%), Pseudomonas putrefaciens 3 sampel (13,6\%), Alcaligenes faecalis 2 sampel (9\%), Proteus mirabilis 2 sampel (9\%), Acinetobacter baumannii 1 sampel (4,5\%), Proteus rettgeri 1 sampel (4,5\%), dan tanpa pertumbuhan bakteri sebanyak 2 sampel (9\%).

Sensitivitas bakteri terhadap antibiotik diperoleh melalui pengukuran diameter zona hambatan yang terbentuk setelah proses penempelan disc antibiotik pada Muller Hinton Agar Plate, dan kemudian hasil pengukurannya dibandingkan dengan standar diameter zona hambatan yang dipakai di laboratorium tersebut. Pada uji kepekaan digunakan 5 jenis disc antibiotik, yaitu amoxycilin, clindamycin, chepalotin, ciprofloxacin dan levofloxacin. Berikut merupakan tabel yang memuat hasil uji kepekaan bakteri terhadap beberapa antibiotik.

Tabel 4.6 Persentase Kepekaan Sensitif Bakteri Terhadap Beberapa Antibiotik

\begin{tabular}{lccccc}
\hline \multirow{2}{*}{ Jenis Kuman } & \multicolumn{4}{c}{ Kepekaan Sensitif (\%) } \\
\cline { 2 - 6 } & AMC & CC & CF & CIP & LVX \\
\hline Staphylococcus aureus $(\mathrm{n}=4)$ & 25 & 25 & 25 & 50 & 75 \\
Pseudomonas aeruginosa $(\mathrm{n}=4)$ & 25 & 25 & 25 & 75 & 75 \\
Enterobacter aerogens $(\mathrm{n}=3)$ & 0 & 0 & 0 & 33,3 & 100 \\
Pseudomonas putrefaciens $(\mathrm{n}=3)$ & 0 & 0 & 0 & 100 & 100 \\
Alcaligenes faecalis $(\mathrm{n}=2)$ & 0 & 0 & 0 & 50 & 50 \\
Proteus mirabilis $(\mathrm{n}=2)$ & 0 & 0 & 0 & 50 & 50 \\
Acinetobacter baumannii $(\mathrm{n}=1)$ & 0 & 0 & 0 & 100 & 100 \\
Proteus rettgeri $(\mathrm{n}=1)$ & 100 & 0 & 0 & 100 & 100 \\
\hline
\end{tabular}

Ket: AMC, Amoxycilin; CC, Clindamycin; CF, Chepalotin; CIP, Ciprofloxacin; LVX, Levofloxacin.

Hasil uji kepekaan pada tabel 4.6 menunjukkan bahwa antibiotik dengan sensitivitas tertinggi adalah Levofloxacin dan Ciprofloxacin 20 sampel (100\%), kemudian Amoxycilin 9 sampel (45\%), serta Clindamycin dan Chepalotin masing-masing 8 sampel (40\%). Angka resistensi tertinggi ditunjukkan oleh antibiotik Clindamycin 20 sampel (100\%), diikuti oleh Amoxycilin dan Chepalotin masing-masing 15 sampel (75\%), lalu Ciprofloxacin dan Levofloxacin 6 sampel (30\%).

\section{BAHASAN}

Penelitian tentang Pola Kuman Penyebab Otitis Eksterna dan Uji Kepekaan Antibiotik di Poliklinik THT-KL BLU RSUP Prof. Dr. R. D. Kandou Manado Periode November - Desember 
2013 telah terlaksanakan dan diperoleh 22 sampel sekret telinga pasien otitis eksterna. Dari 22 sampel yang didapat, 20 sampel menunjukkan pertumbuhan bakteri dan 2 lainnya tanpa pertumbuhan bakteri.

Selama periode penelitian, didapatkan bahwa pasien otitis eksterna terbanyak adalah pada kelompok umur dewasa 15-49 tahun sebanyak 13 orang (59\%). Hal ini tidak jauh berbeda dengan penelitian terdahulu yang dilakukan pada bulan Juni - Juli 2010 di Poliklinik THT-KL BLU RSUP Prof. Dr. R. D. Kandou Manado menunjukkan dari 20 sampel pasien otitis eksterna terbanyak dari kelompok umur 31-45 tahun berjumlah 10 orang (50\%). ${ }^{9}$ Serupa dengan suatu penelitian prospektif tentang otitis eksterna akut di rumah sakit pendidikan Universitas Nigeria menunjukkan dari 127 pasien yang terdiagnosa, pasien terbanyak adalah kelompok usia 23-32 tahun (23,6\%). ${ }^{10}$

Distribusi pasien berdasarkan jenis kelamin menunjukkan bahwa pasien dengan jenis kelamin perempuan merupakan kelompok terbanyak dengan jumlah 15 orang (68,2\%) dibanding dengan jenis kelamin laki-laki yang berjumlah 7 orang (31,8\%). Penemuan ini serupa dengan penelitian Rupawan pada periode Juni - Juli 2010 yang memperoleh data bahwa pasien otitis eksterna terbanyak adalah 12 orang perempuan (60\%) dan sisanya 8 orang laki-laki (40\%). ${ }^{9}$ Tapi hal lain ditemukan pada data klinik dari sebuah penelitian di North Queensland menunjukkan bahwa dari 49 pasien dengan otitis eksterna akut, didominasi oleh pria (72,3\%). ${ }^{11}$ Otitis eksterna tidak dipengaruhi oleh jenis kelamin. ${ }^{10}$ Terjadinya penyakit ini mungkin dipengaruhi oleh kebiasaan individu.

Dari 22 pasien yang ikut dalam penelitian ini, trauma merupakan faktor resiko terbanyak yang teridentifikasi pada pasien (100\%). Hal ini sesuai dengan pernyataan dalam sebuah jurnal yang mengatakan bahwa pemicu otitis eksterna terbanyak adalah trauma (penggunaan cotton swab). ${ }^{12}$ Kulit kanalis eksternal sangatlah sensitif dan mudah rusak. Rusaknya kulit akibat trauma memungkinkan invasi dari bakteri sehingga menyebabkan inflamasi maupun infeksi. ${ }^{13}$

Gejala (symptoms) yang dikeluhkan pasien dengan otitis eksterna dalam penelitian ini didapatkan terbanyak adalah dengan gejala pruritus sebanyak 19 orang (86,3\%) dan diikuti dengan otalgia 17 orang (77,2\%). Hal yang sama dicantumkan pada penelitian Kurnatowski et al yang memperoleh hasil terbanyak adalah gejala pruritus 77,0\% pada infeksi berbagai jenis bakteri. Pada penelitian Manni et al juga dilaporkan bahwa prevalensi gejala tertinggi adalah pruritus 93\%, diikuti dengan keluhan nyeri $82 \%$ dan otore $64 \% .{ }^{14}$ Banyaknya keluhan pruritus ini mungkin disebabkan karena pasien sedang dalam proses permulaan infeksi yang berangsur-angsur berubah menjadi nyeri telinga (otalgia). ${ }^{15}$ 
Terdapat 8 jenis bakteri yang teridentifikasi dan bakteri yang terbanyak adalah Staphylococcus aureus 4 sampel (18,2\%) dan Pseudomonas aeruginosa 4 sampel (18,2\%), kemudian diikuti oleh Enterobacter aerogens 3 sampel (13,6\%), Pseudomonas putrefaciens 3 sampel (13,6\%), Proteus mirabilis 2 sampel (9\%), Alcaligenes faecalis 2 sampel (9\%), Acinetobacter baumannii 1 sampel (4,5\%), dan Proteus rettgeri 1 sampel (4,5\%). Tidak jauh berbeda dengan hasil penelitian Rupawan pada periode Juni - Juli 2010, bakteri terbanyak yang ditemukan adalah Staphylococcus aureus (20\%) dan Klebsiella (20\%). ${ }^{9}$

Dominasi Staphylococcus aureus mungkin disebabkan karena bakteri ini merupakan flora normal yang hidup pada telinga bagian luar dan saat terjadi kerusakan pada kulit liang telinga yang disebabkan oleh faktor misalnya trauma, terjadi invasi dan infeksi oleh Staphylococcus aureus tersebut. $^{16}$

Dominasi bakteri Pseudomonas aeruginosa yang teridentifikasi kemungkinan berhubungan dengan patogenesis dari otitis eksterna yaitu hilangnya mekanisme proteksi dari kanalis eksternal akibat berkurangnya atau hilangnya serumen karena adanya faktor predisposisi (seperti berenang) yang menyebabkan perubahan $\mathrm{pH}$ dari asam menjadi basa sehingga memungkinkan infeksi dari bakteri tersebut. ${ }^{17}$ Oleh sebab itu bakteri Pseudomonas aeruginosa disebut sebagai bakteri oportunistik. $^{18}$

Pada uji kepekaan / sensitivitas digunakan 5 jenis antibiotik yaitu Amoxycilin, Clindamycin, Chepalotin, Ciprofloxacin dan Levofloxacin. Hasil penelitian menunjukkan bahwa antibiotik dengan sensitivitas tertinggi adalah Levofloxacin dan Ciprofloxacin 20 sampel (100\%) dan angka resistensi tertinggi ditunjukkan oleh Clindamycin 20 sampel (100\%). Hasil yang sama dilaporkan pada penelitian Suwu P et al, antibiotik dengan kepekaan tertinggi adalah Levofloxacin sebanyak 14 sampel (77,78\%) dan resistensi kuman tertinggi ditemukan terhadap antibiotik Clindamycin dan Erythromycin sebanyak 18 sampel (100\%). ${ }^{19}$ Tingkat kepekaan sangat dipengaruhi oleh 3 faktor, yaitu faktor bakteri, dokter dan pasien sendiri. Faktor bakteri antara lain karena adanya mekanisme resistensi primer dan sekunder. ${ }^{20}$ Peran dokter dalam resistensi mikroba terhadap antibiotik adalah pemberian antimikroba spektrum luas saat penggunaan antimikroba spektrum sempit saja cukup. Ketidakpatuhan pasien terhadap terapi yang diberikan dokter, penggunaan yang tidak rasional akibat pengobatan sendiri juga turut mempengaruhi tingkat kepekaan mikroba terhadap antibiotik. ${ }^{21}$

\section{KESIMPULAN}

Berdasarkan hasil penelitian dapat disimpulkan bahwa terdapat 8 jenis bakteri yang teridentifikasi dan bakteri yang terbanyak adalah Staphylococcus aureus 4 sampel (18,2\%) dan 
Pseudomonas aeruginosa 4 sampel (18,2\%). Antibiotik dengan sensitivitas tertinggi adalah Levofloxacin dan Ciprofloxacin. Sedangkan angka resistensi tertinggi ditunjukkan oleh Clindamycin, diikuti oleh Amoxycilin dan Chepalotin.

\section{SARAN}

Perlu dilakukan penelitian serupa secara berkala untuk memperoleh data terbaru mengenai pola kuman otitis eksterna dan uji kepekaan terhadap antibiotik guna keperluan klinis. Juga perlu dilakukan pengembangan dalam penelitian berikutnya sebagai perbandingan pemberian terapi pada otitis eksterna dengan menggunakan antibiotik oral dengan terapi standar (topikal).

\section{DAFTAR PUSTAKA}

1. Hafil AF, Sosialisman, Helmi. Kelainan Telinga Luar. Soepardi EA, Iskandar N, Bashiruddin J, Restuti RD. Buku Ajar Ilmu Kesehatan Telinga Hidung Tenggorok Kepala \& Leher. Edisi ke-6. Jakarta: Badan penerbit FKUI; 2011. h. 60-3.

2. Boies LR. Penyakit Telinga Luar. Adams GL, Boies LR, Higler PA. BOIES Buku Ajar Penyakit THT. Edisi ke-6. Jakarta: Penerbit buku kedokteran EGC; 2012. h. 75-80.

3. Guss J, Ruckenstein MJ. Infections of The External Ear. In : Flint PW, Haughey BH, Lund VJ, Niparko JK, Richardson MA, Robbins KT, et al. Cumming Otolaryngology Head \& Neck Surgery. 5rd ed. Philadelphia: Mosby elsevier; 2010. P. 1956-61.

4. Center for Disease Control and Prevention. Estimated Burden of Acute Otitis Externa United States, 2003-2007. Morbidity and Mortality Weekly Report. 2011;60:605-9.

5. Palandeng RW. Otitis Eksterna di Poliklinik THT-KL RSU Prof. Dr. R. D. Kandou Manado Periode Januari - Desember 2011 [skripsi]. Manado: Universitas Sam Ratulangi; 2012.

6. Roland PS, Stroman DW. Microbiology of Acute Otitis Externa. The Laryngoscope. 2002;112:1166-77.

7. Setiabudy R. Pengantar Antimikroba. Gunawan SG, Setiabudy R, Nafrialdi, Elysabeth. Farmakologi dan Terapi. Edisi ke-5. Jakarta: Departemen farmakologi dan terapeutik FKUI; 2009. h. 585-91.

8. Sander R. Otitis Externa: A Practical Guide to Treatment and Prevention. American Family Physician. 2001;63:927-9.

9. Rupawan IK. Pola Kuman dan Kepekaannya Terhadap Antibiotika Pada Penderita Otitis Eksterna di Poliklinik THT BLU RSUP Prof. dr. R. D. Kandou Manado Periode Juni - Juli 2010 [skripsi]. Manado: Universitas Sam Ratulangi; 2010.

10. Ibiam AF, Godwin O, Ezeanolue B, Okoroafor IJ. Acute Otitis Externa as Seen at The University of Nigeria Teaching Hospital, Enugu. Otolaryngology Online Journal. 2013;3. 
11. Cheffins T, Heal C, Rudolphy S. Acute Otitis Externa Management by GPs in North Queensland. Australian Family Physician. 2009;38:262-6.

12. Kujundzic M, Braut T, Manestar D, Cattunar A, Malvic G, Vukelic J, et al. Water Related Otitis Externa. Coll. Antropol. 2012;36:893-7.

13. Waitzman AA. Otitis Externa. 2013 Jan 22 [cited 2014 Jan 14]. Available from: http://emedicine.medscape.com/article/994550-overview\#a0104\

14. Kurnatowski P, Filipiak J. Otitis externa : the analysis of relationship between particular signs/symptoms and species and genera of identified microorganisms. Wiadomooeci Parazytologiczne. 2008;54:37-41.

15. Austin DF. Anatomi dan Embriologi, Penyakit Telinga Luar. Ballenger JJ. Penyakit Telinga, Hidung, Tenggorok, Kepala dan Leher Jilid ke-2. Edisi ke-13. Jakarta: Binarupa Aksara; 1997. h. 105-07, 338-45.

16. Harvey RA, Champe PC, Fisher BD. Staphylococci. Lippincott's Illustrated Reviews. 2nd ed. 2007.

17. Marple BF, Roland PS. External Auditory Canal. In : Roland PS, Marple BF, Meyerhoff WL. Hearing Loss. 1997. P. 139-41.

18. Todar K. Pseudomonas aeruginosa. [cited 2014 Jan 28]. Available from: http://textbookofbacteriology.net/pseudomonas.html

19. Suwu P, Kountul C, Waworuntu O. Pola kuman dan uji kepekaannya terhadap antibiotika pada penderita otitis eksterna di Poliklinik THT-KL RSU Prof. Dr. R. D. Kandou. Jurnal eCliniC. 2013;1:20-25.

20. Pratiwi ST. Mikrobiologi Farmasi. Jakarta: Penerbit Erlangga; 2008. h. 154-61, 165-7.

21. Odonkor ST, Addo KK. Bacteria Resistance to Antibiotics : Recent Trends and Challenges. International Journal of Biological \& Medical Research. 2011;2:1204-10. 